\title{
12. BIOSTRATIGRAPHIC AND PALEOCEANOGRAPHIC EVENTS IN THE EASTERN EQUATORIAL PACIFIC: RESULTS OF DEEP SEA DRILLING PROJECT LEG 691
}

\author{
Constance A. Sancetta, Lamont-Doherty Geological Observatory of Columbia University, Palisades, New York
}

\begin{abstract}
A standard biostratigraphic system, based upon diatom datum levels previously correlated to the paleomagnetic record, was applied to Deep Sea Drilling Project Sites 501/504 and 505. Sedimentation appears to have been constant at the three sites, averaging $50 \mathrm{~m} / \mathrm{m}$.y. at Sites $501 / 504$ and $60 \mathrm{~m} / \mathrm{m}$.y. at Site 505 . Calcium carbonate is rather poorly preserved at both sites, because of depth of water and, at Sites 501/504, alteration by diagenesis. Siliceous microfossils are common and moderately well preserved at the three sites; at Sites 501/504, diatoms disappear abruptly below the first occurrence of chert. The uppermost Miocene diatom assemblage occurs just above chert and is characterized by a strong dominance of Thalassionema and Thalassiothrix, which implies very high silica production during the latest Miocene; the chert probably is derived from a similar assemblage. In the earliest Pliocene, silica production appears to have decreased sharply; about $3 \mathrm{Ma}$, preservation of calcium carbonate also diminished, suggesting a shoaling of the $\mathrm{CCD}$. At $2 \mathrm{Ma}$, there occurred a short interval of low production of both calcium carbonate and silica, which lasted into the earliest Pleistocene.
\end{abstract}

\section{INTRODUCTION}

Sediments at Sites 501/504 and 505, on the south flank of the Costa Rica Rift (Fig. 1), are siliceous calcareous oozes (with diagenetic effects at Sites 501/504); diatoms and calcareous nannofossils are present throughout the section at both sites. Diatoms are somewhat more abundant in the upper Pliocene and lower Pleistocene. They disappear abruptly below the first occurrence of chert at Sites 501/504 (237 m).

Diatom biostratigraphy for the Neogene equatorial Pacific has been well established by Burckle (1977, 1978; Burckle and Trainer, 1979), using the concept of datum levels, which he has correlated with the paleomagnetic events in the same cores. The basis of his work has been sites in the central equatorial Pacific (about $4^{\circ} \mathrm{N}, 140^{\circ}$ W) which lie below the influence of the North Equatorial Current. While a few species have been found to show time-transgressive events between the central and the eastern equatorial Pacific (which is affected by the PeruChile Current), most of these datums have been verified as isochronous throughout the equatorial Pacific (Burckle, 1978; Sancetta, in press).

The diatom biostratigraphic system used here (Fig. 2) is basically that of Burckle. The effect of the cool PeruChile Current upon the diatom assemblage is manifested by the addition of datums for Rhizosolenia matuyamai, a species which Burckle et al. (1978) have reported from the North Pacific. On the other hand, I have not used the extinction datums for Nitzschia fossilis and N. reinholdii, which may be time-transgressive species. $N$. reinholdii is also very rare in the upper part of its range, so that extinction is difficult to determine. Figure 2 gives the zones and subzones originally defined by Burckle (1972), as well as datum levels from his subsequent work, which

\footnotetext{
${ }^{1}$ Cann, J. R., Langseth, M. G., Honnorez, J., Von Herzen, R. P., White, S. M., et al. Init. Repts. DSDP, 69: Washington (U.S. Govt. Printing Office).
}

embraces two species of silicoflagellates as well (Mesocena quadrangula and Dictyocha neonautica). The ages of magnetic events are based on recent revision of the decay rate of ${ }^{40} \mathrm{~K}$ by Mankinen and Dalrymple (1979). For convenience, I have informally divided the early and late Pleistocene at the Brunhes/Matuyama boundary, and the early and late Pliocene at the Gauss/Gilbert boundary.

On Figures 3 and 5, I have also noted datum levels for some calcareous nannofossils at Sites 504 and 505 . However, the nannofossils are not well preserved in this region; many of the stratigraphically important species (particularly Discoaster and Ceratolithus species) are extremely rare, and their extinctions difficult to determine. Stratigraphic and oceanographic analysis is based mostly upon the diatoms.

\section{DIATOM BIOSTRATIGRAPHY AT EACH SITE}

\section{Site 501}

Site 501 was spot-cored (Cores 1-5) down to 226 meters. Consequently, datum levels cannot be determined, and only zonal assignments are given, based on co-occurrence of marker species.

Core $1(0-7.6 \mathrm{~m})$ contains only Pseudoeunotia doliolus among the marker species; it is thus assigned to the $P$. doliolus Subzone B of the upper Pleistocene. Core 2 was taken only to confirm the depth of the mudline, and was not sampled. Core 3 (55.1-64.6 m) has rare Mesocena quadrangula, as well as $P$. doliolus. This, together with the absence of Rhizosolenia praebergonii, limits it to the lower part of the $P$. doliolus Subzone B of the lower Pleistocene. Core 4 (112.1-121.6 m) includes rare $R$. praebergonii and Nitzschia jouseae, along with members of the Thalassiosira convexa group. The core is therefore of late Pliocene age, from the $R$. praebergonii A Subzone. Core 5 (169.1-178.6 m) has rather rare, poorly preserved diatoms. $N$ : jouseae is the only marker 


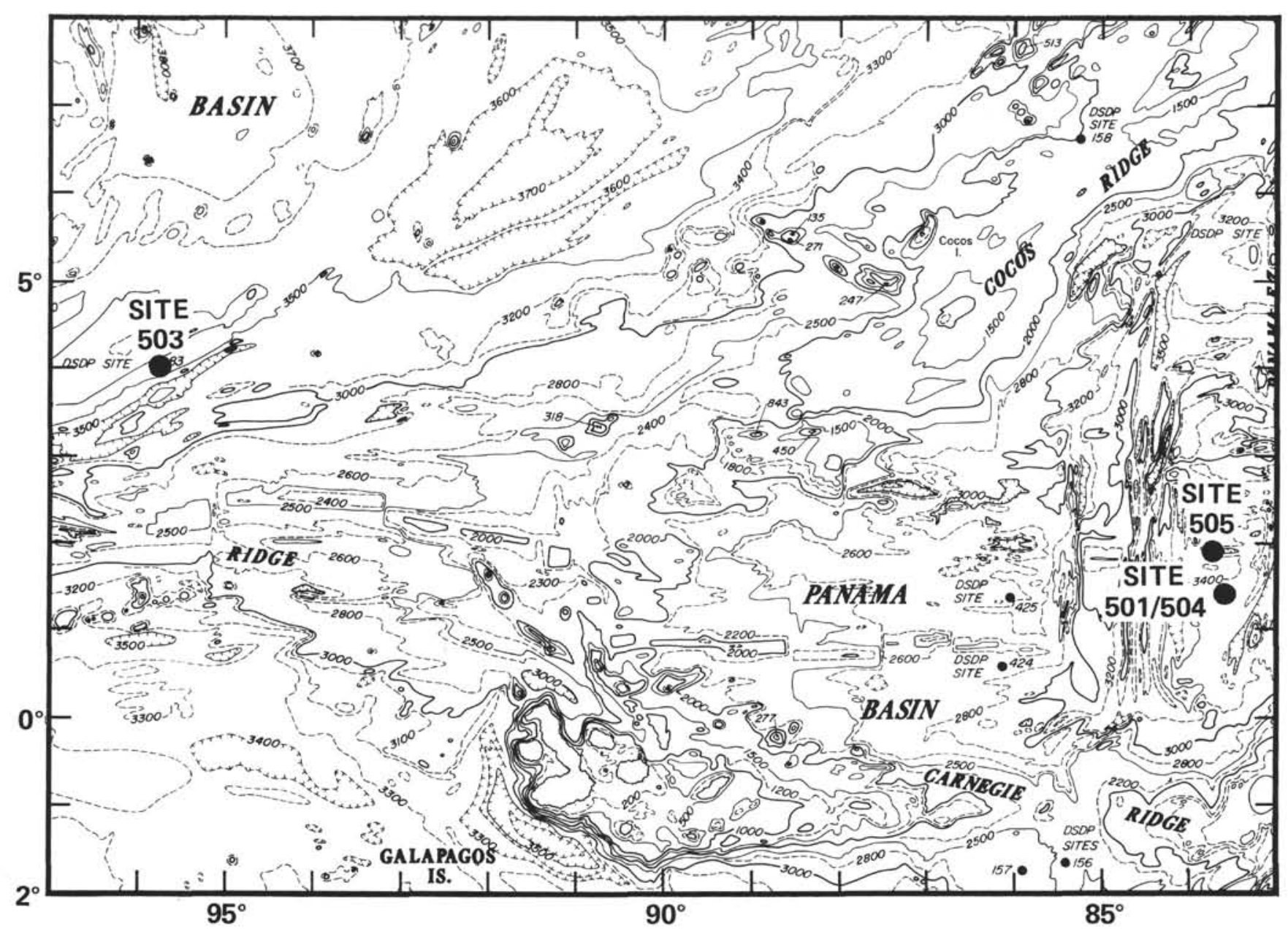

Figure 1. Locations of Sites 501, 504, and 505 in the Panama Basin, south of the Costa Rica Rift, and Site 503 on the Cocos Plate. Bathymetry from Mammerickx and Smith (1981). Contour interval 500 meters, or 100 meters where appropriate.

species seen. This implies an early Pliocene age, and the core probably is from the lower part of the $N$. jouseae Zone.

In Core $6(226.1-235.6 \mathrm{~m})$, where coring became continuous, diatoms are rare and poorly preserved. The only useful information is the presence of Nitzschia cylindrica; this, and the absence of $N$. jouseae, would imply an early Pliocene age (Thalassiosira convexa Subzone C), but the calcareous nannofossils include Discoaster quinqueramus, which became extinct in the late Miocene. It is more probable that the true age is late Miocene, and that Miocene marker diatoms (Thalassiosira miocenica) have been destroyed by dissolution.

In Cores 7 through $9(235.6-264.1 \mathrm{~m})$ diatoms are absent. Calcareous nannofossils are very poorly preserved, but the presence of $D$. quinqueramus confirms a late Miocene age.

\section{Site 504}

Diatoms are present throughout the upper 237 meters of Site 504, and disappear below the first occurrence of chert. They are moderately common and well preserved in the Pleistocene and late Pliocene, but few and rather poorly preserved through the early Pliocene chalky in- terval. In the late Miocene section, just above the chert, they are very common and well preserved-a pattern also present at Site 501 .

Figure 3 shows the ranges and datum levels for the stratigraphically useful diatoms and silicoflagellates. The ages are approximate, based on the correlations from Figure 2. Sample numbers for each datum are listed in Table 1. Figure 3 also includes datums for some calcareous nannofossils. As stated above, preservation of the nannofossils is poor through most of the interval, and some of the marker species are so rare as to be essentially absent. Discoasters are very rare in the uppermost Pliocene, so that the extinction of Discoaster brouweri, usually used to define the Plio/Pleistocene boundary, cannot be located easily.

The Plio/Pleistocene boundary, here marked by the extinction of $R$. praebergonii, occurs at 504-14-2, $14 \mathrm{~cm}$ $(68.7 \mathrm{~m})$, and the Mio/Pliocene boundary, marked by the extinction of $T$. miocenica, occurs at $504-48, C C$ $(215 \mathrm{~m})$. No ages can be assigned for Unit III, in the chalk-limestone-chert interval, but it is presumably late Miocene.

In Hole 504A, diatoms are present only in Core 1, and provide no firm ages. The presence of overgrown $D$. 


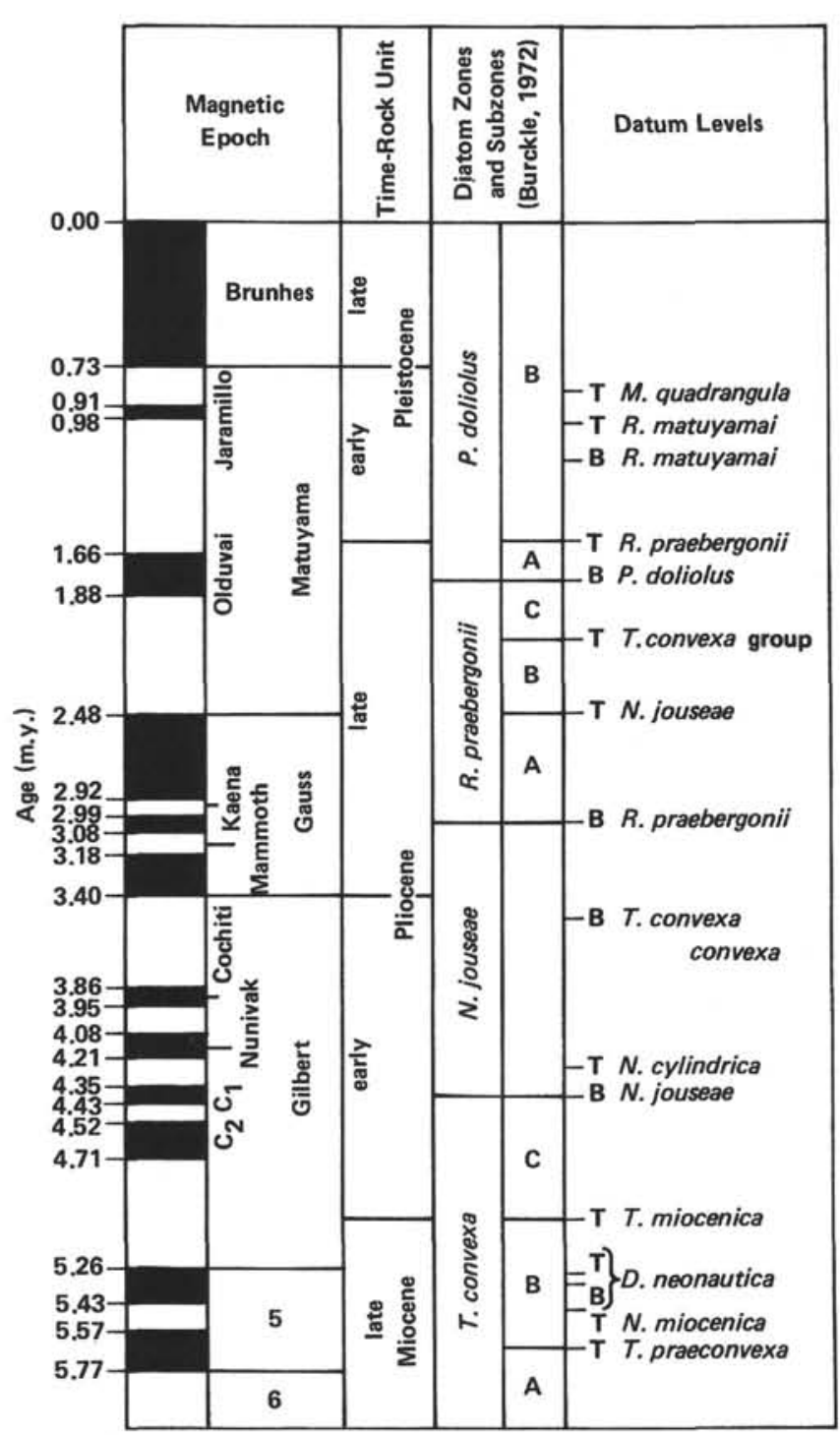

Figure 2. Diatom zonation used for Leg 69. Subdivision of Pliocene and Pleistocene informal. $\mathrm{T}=$ top of range (extinction); $\mathrm{B}=$ base of range (first appearance). Zonation, datum levels, and paleomagnetic correlations from Burckle $(1972,1977,1978$; Burckle and Trainer, 1979; Burckle et al., 1978). Paleomagnetic dates from Mankinen and Dalrymple (1979).

quinqueramus, however, indicates a late Miocene age for Cores 1 through $3(226.5-255.5 \mathrm{~m})$. No age can be assigned to the sediments of Hole 504B, but it also is probably late Miocene, by analogy.

Sedimentation rates for Units I and II, based on the diatom datums, average $50 \mathrm{~m} / \mathrm{m} . y$. (Fig. 4).

\section{Site 505}

Diatoms are present throughout the section at Site 505 , varying from few $(5-20 \%)$ to common $(40-60 \%)$. Preservation is somewhat better through the lower Pleistocene and upper Pliocene than either above or below that interval, but the difference is not strongly marked.

Figure 5 gives the ranges of stratigraphically useful diatoms (and $M$. quadrangula). The ages are approximate, taken from Figure 2. Datum levels are listed in
Table 1. As at Site 504, nannofossils are not always well preserved, and some datums cannot be assigned with certainty. It should be noted that the levels for extinction of $R$. preabergonii and of $N$. jouseae may be as much as 10 meters too low, because of poor recovery across the intervals, which included sections washed during heat-flow measurements. In both cases, extinction is considered to have occurred just above the level of last occurrence (rather than at the level where the species is first absent).

The Plio/Pleistocene boundary may fall within the first washed interval; in Figure 5, it is drawn at the level of last occurrence of $R$. praebergonii and Discoaster brouweri $(505-11-1,121 \mathrm{~cm} ; 96.7 \mathrm{~m})$. The base of the section $(505-24, C C ; 233.5 \mathrm{~m})$ is in the early Pliocene, and must be younger than 4.2 m.y., as Nitzschia cylindrica is absent.

Sedimentation rates at Site 505, based on diatom datums, average $60 \mathrm{~m} / \mathrm{m} . \mathrm{y}$. (Fig. 6).

\section{Comparison of Sites}

Although Sites 504 and 505 are very close to each other (about $80 \mathrm{~km}$ apart), sedimentation rates at Site 505 are almost $10 \mathrm{~m} / \mathrm{m}$.y. greater than at Site 504. This may be due to the location of Site 505 in a small graben, so that excess material from the graben walls may have been added to the section. There is minor reworking in the lower Pleistocene (Core 505-7; $50 \mathrm{~m}$ ), but no sign of significant reworking, so that addition of material has been continuous, rather than episodic, and has not involved erosion of older outcrops.

\section{ABUNDANCE AND PRESERVATION OF DIATOMS AND CALCAREOUS NANNOFOSSILS}

Because of the proximity of the two sites, Site 505 fossils may be treated as representative of the condition of Site 504 fossils prior to diagenesis. Trends at both sites, then, indicate oceanographic events, while differences may be ascribed to diagenesis at Site 504.

The most obvious differences are in the lower Pliocene, which consists of chalk at Site 504. Here the discoasters, which are very rare, show progressive overgrowth with increasing depth, whereas no overgrowth occurs at Site 505; the overgrowth is first evident at about Core 504-33 (152 m), about 10 meters below the boundary between Unit I and Unit II. By Core 504-40 $(185 \mathrm{~m})$, overgrowth is well advanced, so that some discoasters cannot be identified. In all samples in the chalk interval, overgrowth varies somewhat, so that some specimens appear relatively clean while others are more heavily affected.

In this same interval, diatoms are rather rare and poorly preserved, at both sites. This is probably because of lower productivity of diatoms during the early Pliocene, rather than to dissolution of silica in the chalk. Calcium carbonate content is higher at both sites in the lower Pliocene (sediments older than $3 \mathrm{~m} . \mathrm{y}$.), than in the younger part of the section (Fig. 7), so that low numbers of diatoms in the chalk interval of Site 504 do not necessarily indicate silica diagenesis; this inference is supported by the abrupt increase in diatom abundance 


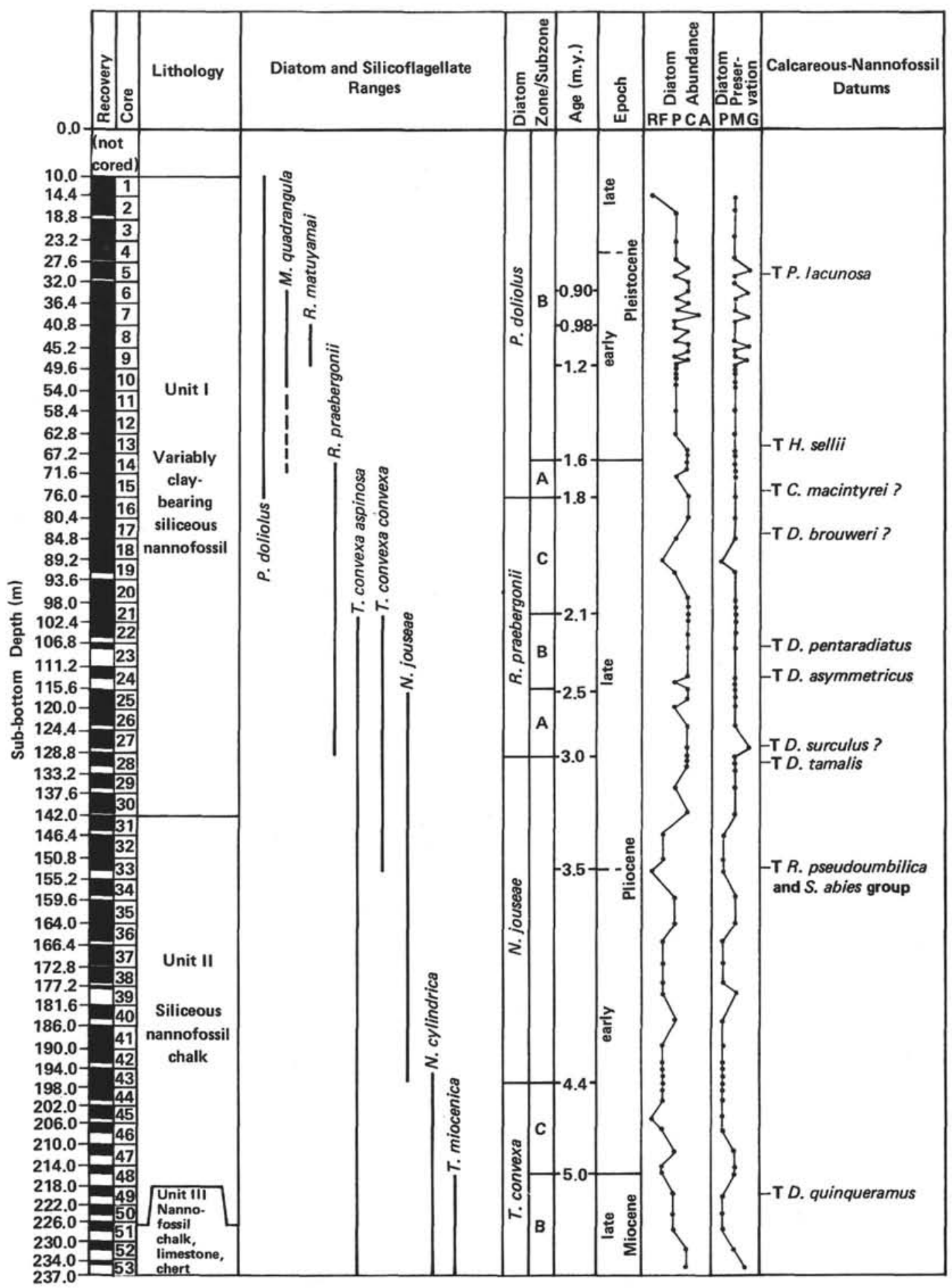

Figure 3. Biostratigraphy at Site 504. Ages are approximate, from Figure 2. For diatom abundance, $R=$ rare $(<5 \%), \mathrm{F}=$ few $(5-20 \%), \mathrm{P}=$ present $(20-40 \%), \mathrm{C}=$ common $(40-60 \%), \mathrm{A}=$ abundant $(>60 \%)$. For diatom preservation, $\mathrm{P}=$ poor, $\mathrm{M}=$ moderate, $\mathrm{G}=$ good.

and preservation (Plate 1) in the part of the section immediately above the chert-limestone unit (Cores 504-52 and 504-53; 504A-1; 501-6; 226-237 m). For further discussion of the possible significance of this change, see the section on paleoceanography and Hein et al. (this volume).
Diatoms are moderately common and well preserved through the late Pliocene section at both sites (Figs. 3 and 5); they are slightly more common at Site 504 than at Site 505, which may be due to Site 504 being lower on the subsidence curve, so that less calcium carbonate has been preserved. Calcareous nannofossils are common 
Table 1. Sample levels of diatom and silicoflagellate datums, Sites 504 and 505. T = top of range (extinction); $\mathrm{B}=$ base of range (first appearance).

\begin{tabular}{|c|c|c|c|}
\hline & Datum & $\begin{array}{l}\text { Site } \\
504\end{array}$ & $\begin{array}{l}\text { Site } \\
505\end{array}$ \\
\hline $\mathrm{T}$ & M. quadrangula & $6-2,14 \mathrm{~cm}$ & $7-5,111 \mathrm{~cm}$ \\
\hline $\mathrm{T}$ & R. matuyamai & $7, \mathrm{CC}$ & 7,33 \\
\hline B & R. matuyamai & $9-3,14 \mathrm{~cm}$ & $9-1,121 \mathrm{~cm}$ \\
\hline $\mathrm{T}$ & R. praebergonii & $14-2,14 \mathrm{~cm}$ & $11-1,121 \mathrm{~cm}$ \\
\hline B & P. doliolus & $15, \mathrm{CC}$ & $12, \mathrm{CC}$ \\
\hline $\mathrm{T}$ & T. convexa group & $21-3,14 \mathrm{~cm}$ & $14, \mathrm{CC}$ \\
\hline $\mathrm{T}$ & N. jouseae & $25-1,14 \mathrm{~cm}$ & $16, \mathrm{CC}$ \\
\hline B & R. praebergonii & $28-1,14 \mathrm{~cm}$ & $18, \mathrm{CC}$ \\
\hline B & T. convexa convexa & $33, \mathrm{CC}$ & $19, \mathrm{CC}$ \\
\hline $\mathrm{T}$ & N. cylindrica & $43-1,14 \mathrm{~cm}$ & - \\
\hline B & N. jouseae & $43-3,14 \mathrm{~cm}$ & - \\
\hline $\mathrm{T}$ & T. miocenica & $48, \mathrm{CC}$ & - \\
\hline
\end{tabular}

and moderately well preserved through most of the interval at both sites.

In the uppermost Pliocene and lowermost Pleistocene at both sites (504-14 to 504-17, 67-85 m; and 505-11 to $505-13,95-124 \mathrm{~m}$ ), the abundance and preservation of calcareous nannofossils show a distinct drop, coincident with an increase in clays. Diatoms show a similar decline, with an increase in more-resistant species. This argues a change in surface-water productivity, rather than a shoaling of the CCD (see paleoceanography section).

The Pleistocene section was not sampled closely, so that fluctuations in abundance and species composition of calcareous and siliceous fossils, which might be related to alternate glacial and interglacial events, cannot be distinguished. Apparent variations within this interval (Figs. 3 and 5) thus may be due to fortuitous position of the examined samples. In general, calcareous nannofossils are common and well preserved throughout, perhaps somewhat less so in the lower Pleistocene. Diatoms are moderately common and well preserved throughout the Pleistocene. The apparent increase of diatom abundance in the uppermost part of Site 505 (Fig. 5) may relate to the increase in clays in the same interval (Cores 505-1 and 505-2; 0-10 m), or the apparent increase may be due to chance location of samples at low points on the calcium carbonate curve.

\section{PALEOCEANOGRAPHY}

\section{Species Composition of Assemblages}

Calcareous nannofossils show relatively little change in species composition of assemblages, aside from those changes due to evolutionary events. The assemblages are dominated by small coccoliths. Ceratoliths are very rare, and in many intervals discoasters are also rare.

Diatom assemblages consist of species typical of the eastern equatorial upwelling regime. There are no significant intrusions of species representative of other water masses. A typical assemblage might show the following distribution:

Present $(20-40 \%$ of the flora): Thalassionema and Thalassiothrix species, Coscinodiscus nodulifer, Hemidiscus cuneiformis, Pseudoeunotia doliolus (Pleistocene), Nitzschia fossilis and Thalassiosira convexa group (Pliocene), Nitzschia jouseae (early Pliocene).

Few (5-20\% of the flora): Thalassiosira eccentrica, $T$. leptopus, $T$. oestrupii, Nitzschia marina, Coscinodiscus crenulatus, Rhizosolenia species, Ethmodiscus rex (fragments).

Rare ( $<5 \%$ of the flora): Asteromphalus species, Actinoptychus species, Coscinodiscus radiatus, C. africanus, Actinocyclus octonarius, A. ellipticus, Nitzschia interrupta, $N$. reinholdii (lower Pleistocene and deeper), Triceratium species.

A. octonaruis, A. ellipticus, and Triceratium species are more common in the lowermost Pliocene than in the younger part of the section, while $T$. oestrupii, $C$. crenulatus, and $C$. radiatus are rarer in older sediments. Otherwise, the only significant variations occur in E. rex and the Thalassionema/Thalassiothrix group.

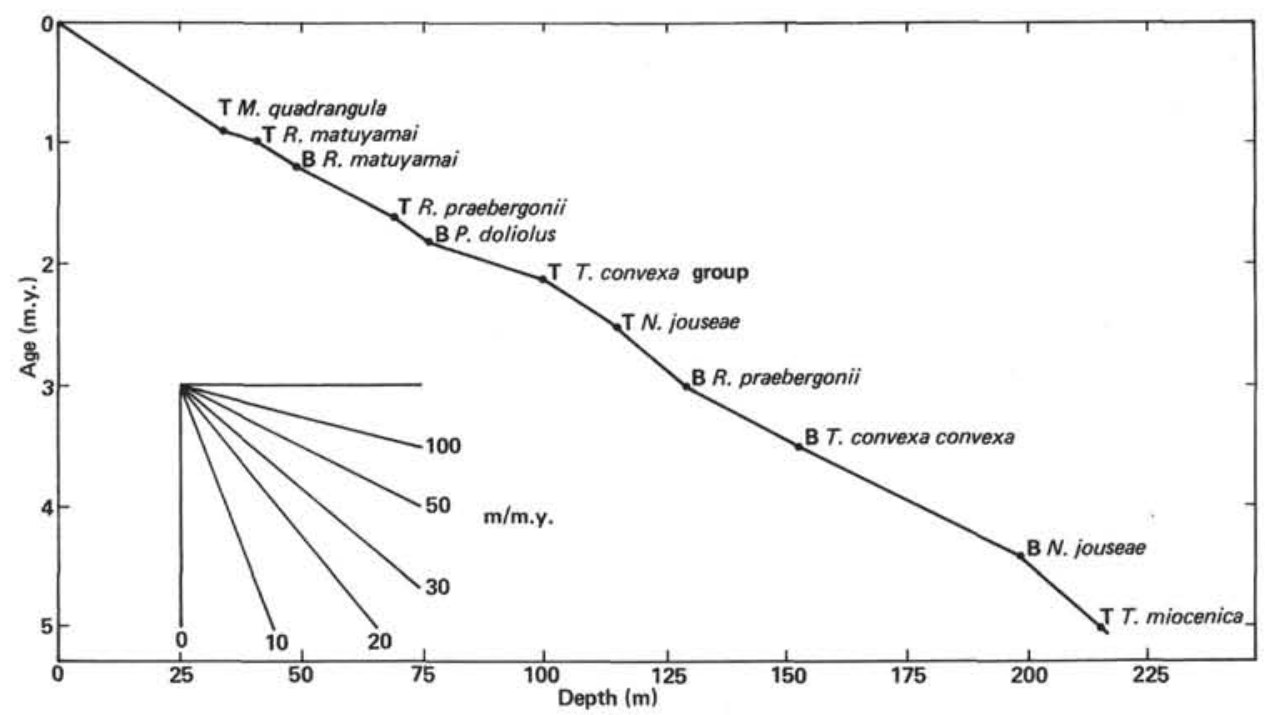

Figure 4. Age-depth curve for Site 504. Ages are from extrapolation to magnetics (Fig. 2). 


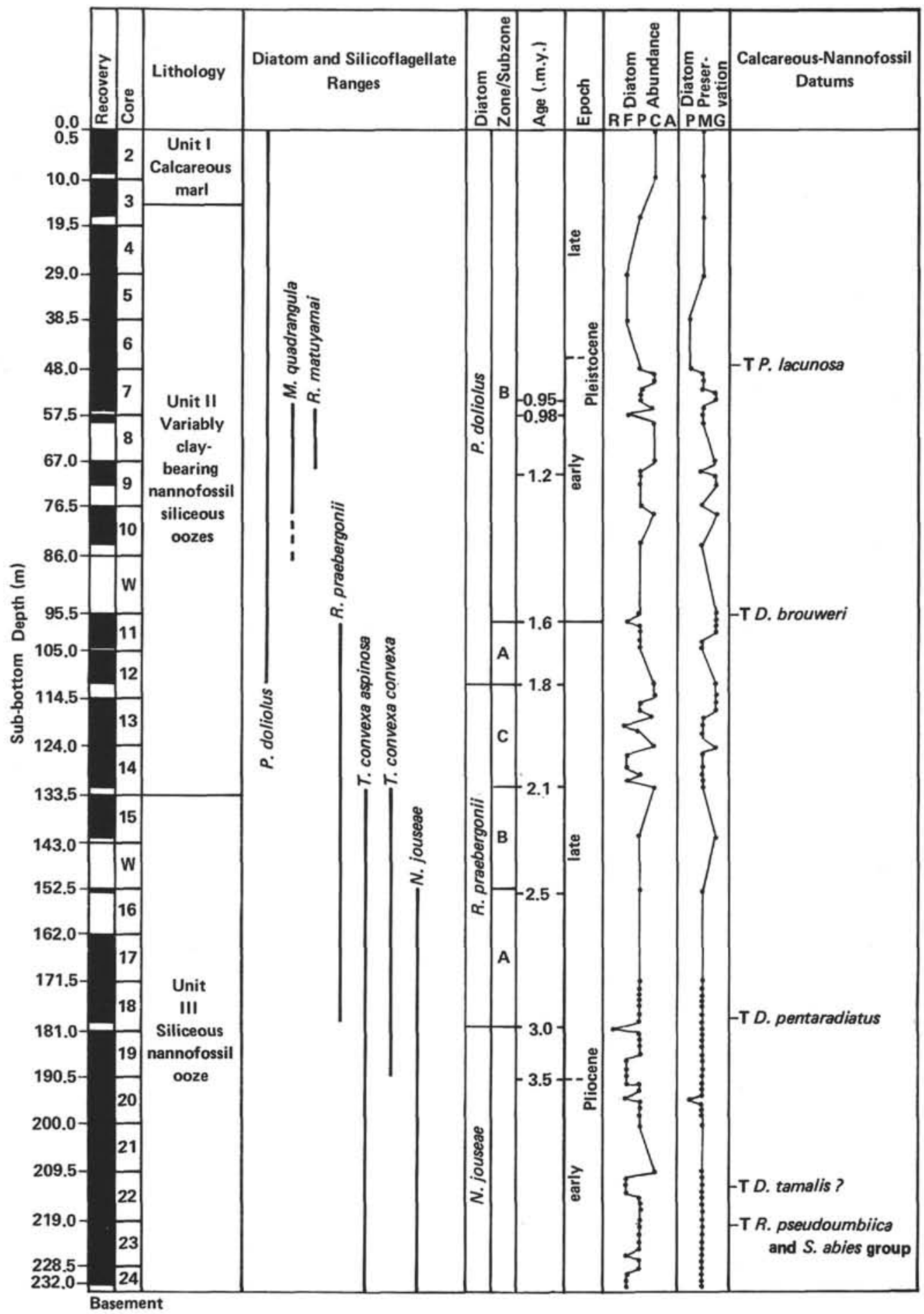

Figure 5. Biostratigraphy at Site 505. Ages are approximate, from Figure 2. Abundance and preservation notation as in Figure 3.

E. rex fragments are normally a rather minor, though consistent, component of the assemblage. At both sites, however, in the clay-bearing interval across the Plio/ Pleistocene boundary, E. rex fragments are common, and in some cases dominate the assemblage. Mikkelsen (1977) has shown that $E$. rex is very resistant to dissolution, and the increased abundances in this interval, which coincide with an increase in clays and a decrease in nannofossil abundance, imply an interval of lowered oceanic productivity and decreased sedimentation rates.

\section{Significance of the Thalassionema Group}

Thalassionema and Thalassiothrix (hereinafter referred to as the Thalassionema group) also increase in abundance in the clay-bearing interval, although they are common throughout the section. In addition, this 


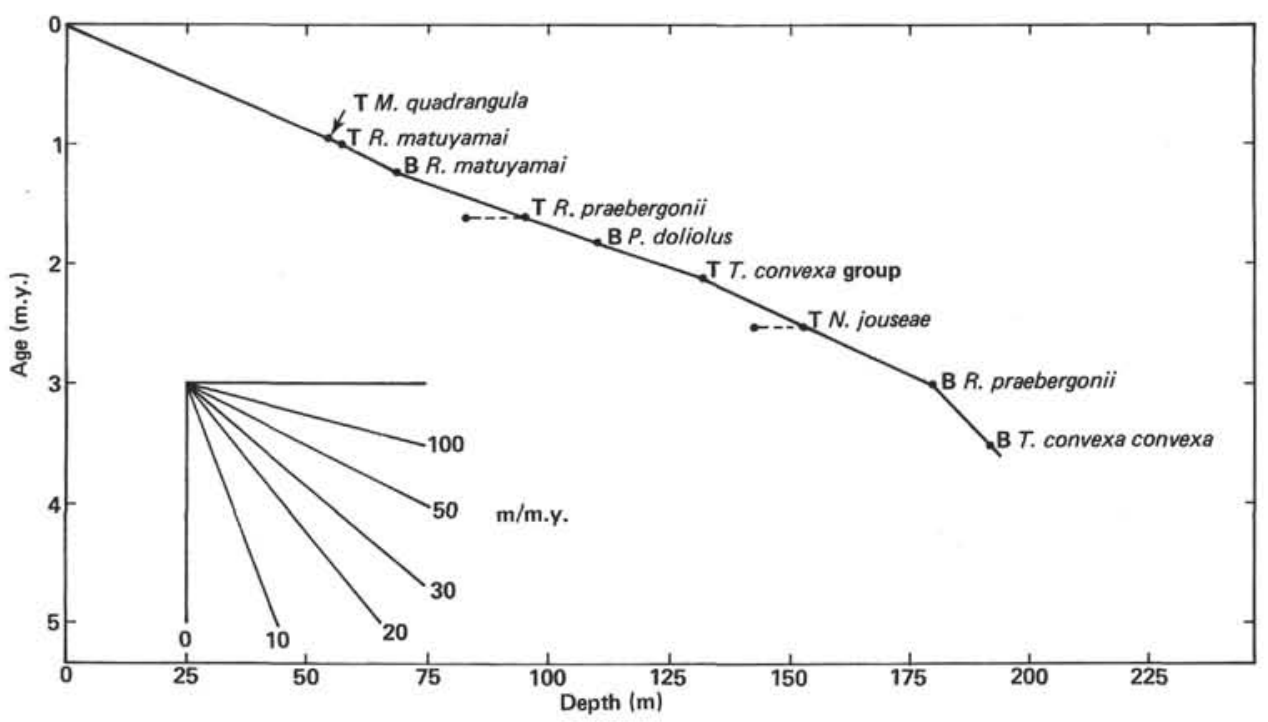

Figure 6. Age-depth curve for Site 505. Ages are from extrapolation to magnetics (Fig. 2).

group becomes dominant in the lower part of the chalk section at Site 504 (Cores 504-40 through 504-53, 180$237 \mathrm{~m}$ ). This is particularly noticeable in the two lowest cores (Cores 504-52 and 504-53), in the upper Miocene chalk just above the chert (Plate 1).

The high abundance of this group during the late Miocene appears to have been characteristic of the entire equatorial Pacific. Bukry and Foster (1973) reported that these genera are most common in sediments representing the same time interval at Sites 157 and $158\left(1^{\circ}\right.$ $45^{\prime} \mathrm{S}, 85^{\circ} 54^{\prime} \mathrm{W}$ and $6^{\circ} 37^{\prime} \mathrm{N}, 85^{\circ} 14^{\prime} \mathrm{W}$ ), and Bukry (1973) reported "common occurrences"' in the "upper Miocene or Pliocene”' at Site $166\left(3^{\circ} 45^{\prime} \mathrm{N}, 175^{\circ} 4^{\prime} \mathrm{W}\right)$. At Site $503\left(4^{\circ} 4^{\prime} \mathrm{N}, 95^{\circ} 38^{\prime} \mathrm{W}\right)$, I found that the abundance of this group showed sporadic increases in the earliest Pliocene and that it is consistently the dominant component of the diatom flora in the upper Miocene (Sancetta, in press). Samples with lesser amounts of calcium carbonate at this site might be accurately termed a Thalassionema ooze.

Bukry and Foster (1973) first suggested that high abundances of Thalassionema in sediments might indicate significant upwelling and biologic productivity. This appears to be borne out by our knowledge of the distribution of this group in modern plankton and sediments. Abbott and Cielsieski (pers. comm.) have found monospecific masses of this group in plankton tows from the Antarctic Convergence. Hasle (1960) found Thalassionema nitzschioides to be the most common species in water samples from the central equatorial Pacific $\left(0-2^{\circ}\right.$ $\mathrm{N}, 145^{\circ} \mathrm{W}$ ), and Hasle and de Mendiola (1967) found "'great quantities"' of a closely related species ( $T$. bacillaris) in Peruvian coastal waters and the West African upwelling region. In modern sediments, Burckle (pers. comm.) has found it to be common or dominant below the Peru-Chile Current and the Antarctic Convergence, whereas I found it to be the dominant species in sediments below the Kuroshio Current (Sancetta, 1979). All of these are regions of major oceanic upwelling and pro- ductivity. It seems probable that the high numbers of this group in the late Miocene equatorial Pacific indicate an interval of sustained upwelling across the region, with heightened productivity.

\section{Paleoceanographic Events}

Combining results from Site 503 and Sites 504/505, we can derive a general impression of oceanographic events in the eastern equatorial Pacific (Fig. 7). The carbonate curve and diatom abundances at Site 503 show that the latest Miocene was a time of high productivity for both calcareous and siliceous organisms. The particularly high numbers of the Thalassionema group suggest major upwelling of the Peru-Chile Current, which is ultimately derived from Antarctic Intermediate Water. If this be true, the cherts and limestones at Site 504 represent the final phase of this productive period, which appears to have ceased shortly after the Mio/Pliocene boundary (Fig. 7). The sharp decrease of the Thalassionema group above this level, coincident with an overall decrease in diatom abundance, indicates a major shift in patterns of productivity and upwelling. Significantly, Brewster (1980), comparing the accumulation rate of opal in the Southern Ocean with that in the equatorial Pacific (Leinen, 1979), notes that near the Mio/Pliocene boundary sedimentary accumulation of opal shifted from the equatorial Pacific to the Southern Ocean, in conjunction with intensification of the Polar Front, so that the latter region became a trap for oceanic silica.

At Site 503 (1000 miles west of Sites 504/505), underlying the North Equatorial Current, the entire Pliocene was a time of relatively low productivity and poorer preservation of calcium carbonate (the poorer preservation also probably due to subsidence of the site, and northward movement away from the zone of high productivity). At Sites 504 and 505, in the eastern equatorial Pacific, productivity of calcareous organisms appears to have remained high until about $3 \mathrm{Ma}$ (Fig. 7), although 


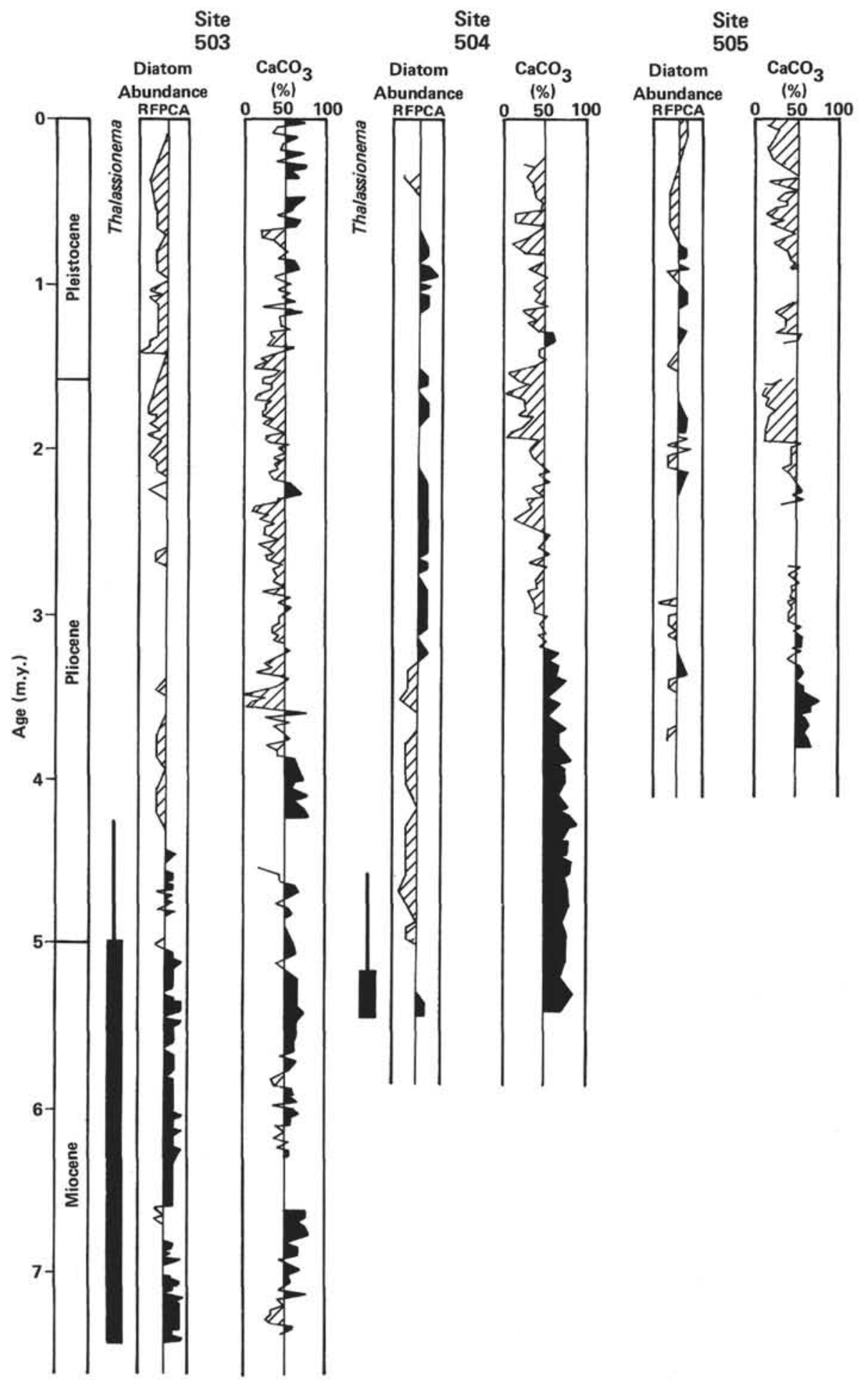

Figure 7. Carbonate curves and diatom abundances for Sites 503, 504, and 505. For each site, depth of sample has been converted to age, using ages of key diatom datums and assuming constant sedimentation rate between datums. Abundance values as in Figure 3. Carbonate data for Site 503 from Gardner (pers. comm.), for Sites 504 and 505 from shipboard measurements. Abundance of Thalassionema group shown by bar width; wide portion indicates $>90 \%$ of assemblage, narrow bar indicates 60 to $90 \%$ of assemblage. 
siliceous fossils decreased in abundance. This may indicate warmer waters and less vigorous upwelling, because diatoms-particularly the Thalassionema group-seem to thrive in cooler waters.

About $3 \mathrm{Ma}$, an abrupt change occurred in the eastern equatorial Pacific, as preservation of calcium carbonate worsened, while abundance of siliceous organisms increased. While this may be in part an effect of subsidence, the fact that it occurs at both sites at the same interval suggests that there also may have been shoaling of the CCD. Keigwin (1979) stated that ${ }^{18} 0$ content of benthic foraminifers at nearby Site 157 shows a tendency to increase at 3.2 to $3.0 \mathrm{Ma}$; he suggested that this was related to initiation of northern-hemisphere ice accumulation (see also Berggren, 1972; Shackleton and Opdyke, 1977; and Keigwin and Thunell, 1979 for discussions of the timing of this event). The matter is complicated by the fact that the Isthmus of Panama was shoaling rapidly during this time (Keigwin, 1978, and references therein), which undoubtedly affected depositional events at Sites 504/505, possibly by forcing Pacific waters to turn westward, which could have resulted in an increase in upwelling.

Between 2 and $3 \mathrm{Ma}$, production and preservation of calcareous tests were only moderate, while diatom abundance was relatively increased. At about $2 \mathrm{Ma}$, a short ( 0.5 m.y.) interval of shoaling of the CCD and decreased productivity occurred. This interval can be seen, though less clearly, at Site 503 as well (Fig. 7). At all three sites, the carbonate curve shows a marked low (typically 20$30 \%$ carbonate), and preservation of calcareous nannofossils is poor. At Sites 504 and 505, the interval shows significant clay content, and the diatoms are dominated by resistant species. The increase in clay and the poor preservation of diatoms suggest that the interval was one of overall decrease in biologic productivity, and not simply increased dissolution of calcite by bottom waters; in other words, the event was a result of surface-water effects, rather than a change in the bottom water. The poor preservation of fossils makes the Plio/Pleistocene boundary hard to define, but at the same time the very lack of fossils indicates the occurrence of a "boundary" event-because period and epoch boundaries are usually defined by abrupt changes in the fossil assemblages.

Events of the Pleistocene cannot be determined here, because of the wide sampling interval. At all three sites, there are fluctuations in the carbonate curve, total carbonate usually being less than $50 \%$ in the eastern equatorial Pacific. Relative abundance of diatoms also shows fluctuations (Fig. 7), but the wider sampling interval does not permit correlation with the carbonate curve.

\section{REFERENCES}

Berggren, W. A., 1972. Late Pliocene-Pleistocene glaciation. In Laughton, A. S., Berggren, W. A., et al., Init. Repts. DSDP, 12: Washington (U.S. Govt. Printing Office), 953-964.

Brewster, N. A., 1980. Cenozoic biogenic silica sedimentation in the Antarctic Ocean. Geol. Soc. Am. Bull., 91:337-347.

Bukry, D., 1973. Phytoplankton stratigraphy, central Pacific Ocean, Deep Sea Drilling Project, Leg 17. In Winterer, E. L., Ewing, J. I., et al., Init. Repts. DSDP, 17: Washington (U.S. Govt. Printing Office), 871-890.

Bukry, D., and Foster, J. H., 1973. Silicoflagellate and diatom stratigraphy, Leg 16, DSDP. In van Andel, Tj. H., Heath, G. R., et al., Init. Repts. DSDP, 16: Washington (U.S. Govt. Printing Office), 815-872.

Burckle, L. H., 1972. Late Cenozoic planktonic diatom zones from the eastern equatorial Pacific. Nova Hedwigia Beih., 39:217-246. 1977. Pliocene and Pleistocene diatom datum levels from the equatorial Pacific. Quat. Res. 7:330-340. 1978. Early Miocene to Pliocene diatom levels for the equatorial Pacific. Geol. Res. Dev. Centre, Republic Indonesia, Spec. Pub., 1:25-44.

Burckle, L. H., Hammond, S. R., and Seyb, S. M., 1978. A Stratigraphically important new diatom from the Pleistocene of the North Pacific. Pacific Sci., 32:209-214.

Burckle, L. H., and Trainer, J., 1979. Middle and Late Pliocene diatom datum levels from the central Pacific. Micropaleontol., 25:281-293.

Hasle, G. R., 1960. Phytoplankton and ciliate species from the tropical Pacific. Skrif. Norske Videns.-Akad. Oslo, Math.-Naturv. Kl., 2:1-50.

Hasle, G. R., and de Mendiola, B. R. E., 1967. The fine structure of some Thalassionema and Thalassiothrix species. Phycology, 6: 107-125.

Keigwin, L. D., 1978. Pliocene closing of the Isthmus of Panama, based on biostratigraphic evidence from nearby Pacific Ocean and Caribbean Sea cores. Geology, 6:630-634.

, 1979. Late Cenozoíc stable isotope stratigraphy and paleoceanography of DSDP sites from the east equatorial and central North Pacific Ocean. Earth Planet. Sci. Lett., 45:361-382.

Keigwin, L. D., and Thunell, R. C., 1979. Middle Pliocene climatic change in the western Mediterranean from faunal and oxygen isotope trends. Nature, 282:294-296.

Leinen, M., 1979. Biogenic silica accumulation in the central equatorial Pacific and its implications for Cenozoic paleoceanography: summary. Geol. Soc. Am. Bull., 90:801-803.

Mammerickx, J., and Smith, S. M., 1981. Bathymetry of the northeast Pacific. Geol. Soc. Am. Map Chart Ser., MC-13.

Mankinen, E. A., and Dalrymple, G. B., 1979. Revised geomagnetic polarity time scale for the interval 0-5 m.y. BP. J. Geophys. Res., 84:615-626.

Mikkelsen, N., 1977. Silica dissolution and overgrowth of fossil diatoms. Micropaleontol., 23:223-226.

Sancetta, C. A., 1979. Oceanography of the North Pacific during the last 18,000 years: evidence from fossil diatoms. Mar. Micropaleontol., 4:103-123.

in press. Diatom biostratigraphy and paleoceanography from Leg 68, DSDP. In Prell, W. L., Gardner, J. V., et al., Init. Repts. DSDP, 68: Washington (U.S. Govt. Printing Office).

Shackleton, N. J., and Opdyke, N. D., 1977. Inception of northern hemisphere glaciation: oxygen isotope and paleomagnetic evidence. Nature, 270:216-218. 

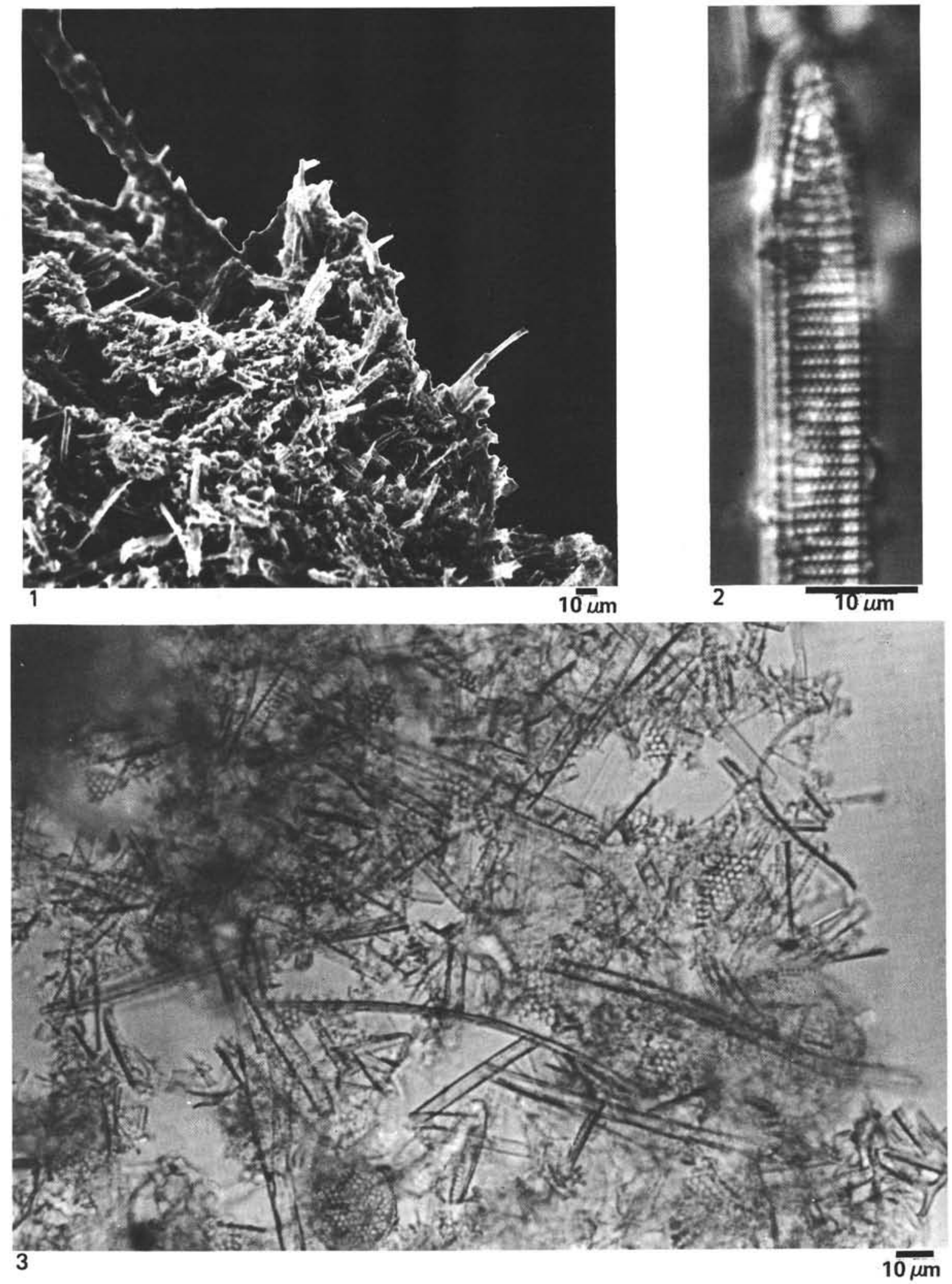

Plate 1. Diatoms from 504-53,CC, just above the first occurrence of chert, showing excellent preservation and abundance. 1. SEM photo showing high numbers of the Thalassionema group. 2. Specimen of Nitzschia marina, showing excellent preservation, with transverse striae intact. 3. LM photo of smear slide from 504-53,CC, showing high numbers of diatoms, especially Thalassionema group. 